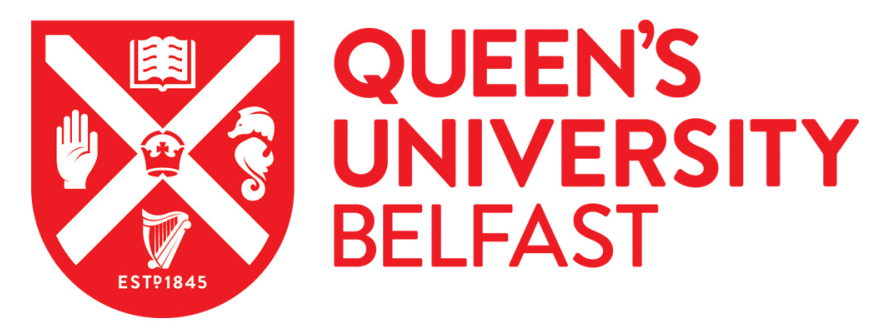

\title{
Self-reported psychosocial needs and health-related quality of life of colorectal cancer survivors
}

\author{
Santin, O., Murray, L., Prue, G., Gavin, A., Gormley, G., \& Donnelly, M. (2015). Self-reported psychosocial \\ needs and health-related quality of life of colorectal cancer survivors. European Journal of Oncology Nursing, \\ 19(4), 336-342. https://doi.org/10.1016/j.ejon.2015.01.009
}

Published in:

European Journal of Oncology Nursing

Document Version:

Peer reviewed version

Queen's University Belfast - Research Portal:

Link to publication record in Queen's University Belfast Research Portal

Publisher rights

(c) 2015, Elsevier. Licensed under the Creative Commons Attribution-NonCommercial-NoDerivatives 4.0 International

$\mathrm{http}: / /$ creativecommons.org/licenses/by-nc-nd/4.0/ which permits distribution and reproduction for non-commercial purposes, provided the author and source are cited.

\section{General rights}

Copyright for the publications made accessible via the Queen's University Belfast Research Portal is retained by the author(s) and / or other copyright owners and it is a condition of accessing these publications that users recognise and abide by the legal requirements associated with these rights.

Take down policy

The Research Portal is Queen's institutional repository that provides access to Queen's research output. Every effort has been made to ensure that content in the Research Portal does not infringe any person's rights, or applicable UK laws. If you discover content in the Research Portal that you believe breaches copyright or violates any law, please contact openaccess@qub.ac.uk. 


\begin{abstract}
Purpose of the research: To investigate the prevalence and nature of unmet needs among colorectal cancer (CRC) survivors and the relationship between needs and quality of life (QoL). Methods and sample: Using the Northern Ireland Cancer Registry (NICR) as a sampling frame and working in collaboration with primary care physicians or GPs, the Cancer Survivors Unmet Needs (CaSUN) questionnaire and the Quality of Life in Adult Cancer Survivors Scale (QLACS) were posted to a randomly selected sample of 600 CRC survivors.
\end{abstract}

Key results: Approximately 70\% (413/600) met eligibility criteria for participation in the study; and 30\% (124/413) responded to the survey. A comparative analysis of NICR data did not indicate any systematic bias between respondents and non-respondents except that respondents appeared to be relatively younger (65 years vs. 67 years). Approximately 60\% of respondents reported that they did not have any unmet needs; $40 \%$ reported one or more unmet health and social care needs such as fear of recurrence, information needs, difficulty obtaining travel insurance and car parking problems. QoL was significantly poorer for CRC survivors who reported an unmet need. Higher scores (poorer QoL) were associated with fatigue problems, concerns about welfare benefits and distress recurrence.

Conclusions: Overall, the majority of CRC survivors who had care needs appeared to have needs that were mainly psychosocial in nature and these unmet needs were related to poorer QoL. There would appear to be merit in considering ways in which to identify the small group of CRC survivors who report unmet needs and devising and delivering targeted psychosocial support programmes or person-centred packages.

Keywords: unmet needs, colorectal cancer survivors, quality of life 


\section{Introduction}

Currently, cancer survivors represent 3\% of the United Kingdom (UK) population (Horner et al., 2006 and Maddams et al., 2009); and colorectal cancer (CRC) is the fourth most common cancer in the UK with approximately 110 new cases diagnosed daily (CRUK, 2014). In 2008, approximately 334,000 people were diagnosed with CRC (CRUK, 2014). The number of people living with CRC as a chronic illness is increasing due to improved detection and survival (Maddams et al., 2009) and this change in the cancer population highlights a need for long-term cancer care planning (Bray et al., 2013).

Service planners and providers need to consider the health and social care requirements for cancer survivorship as cancer patients and their caregivers experience poorer health than the general population several years after treatment has ended (Santin et al., 2012, Santin et al., 2013, Elliott et al., 2011, Hewitt et al., 2003, Schultz et al., 2003, Yabroff et al., 2004, Deimling et al., 2005, Keating et al., 2005, Nord et al., 2005, Eakin et al., 2007 and Reeve et al., 2009). There is common agreement that there is a need to reconfigure current follow-up services for cancer patients in order to improve the match between care needs and service responses and to improve the efficiency and effectiveness of the cancer care system. The current configuration of the clinical follow-up system for CRC patients does not meet their post-treatment needs (Beaver et al., 2010). The transformation of the follow-up care system is at an early developmental stage in Northern Ireland and the rest of the UK; and it has been slow to develop in the rest of Europe (Rowland et al., 2013). In order to plan appropriate care for cancer survivors, the devolved governments of the UK in partnership with the voluntary sector have commissioned a number of projects to examine the health and wellbeing and service requirements of cancer patients post-treatment. Cancer population needs assessments are vital components in this knowledge generation (Richards et al., 2011), and it is imperative that this knowledge is disseminated to improve health care for cancer survivors across Europe (Rowland et al., 2013). Needs assessments assist in the prioritisation and allocation of services (Bonevski et al., 2000 and Spiegel et al., 1994); and in ensuring that patients and their families experience high quality treatment and support (Thewes et al., 2004).

The few studies that have measured the needs of cancer survivors have used different methodologies and produced inconsistent findings (Thewes et al., 2004; Barg et al., 2007; Beesley 
et al., 2007; Hodgkinson et al., 2007; Zeebrack et al., 2007; Armes et al., 2009; Molassiotis et al., 2010; Harrison et al., 2011). For example, they have focused on female cancers (Thewes et al., 2004, Beesley et al., 2007 and Hodgkinson et al., 2007), younger cancer survivors (Zeebrack et al., 2007) and early stage survivorship (Armes et al., 2009); and they have used nonpsychometrically validated measures of need (Barg et al., 2007). Furthermore, the relationship between the impact that cancer has on QoL and needs for care is unclear (Gotay et al., 2007). Although QoL instruments do not directly measure needs, often, needs are implied from these measures (Hodgkinson et al., 2007). A conceptually clear and methodologically robust approach is required in order to address the lack of research in this area and to assess systematically the needs and QoL of cancer survivors and examine the relationship between care needs and QoL. There is an increasing role for the clinical nurse specialist to provide holistic care for patients in the context of newly reconfigured models of cancer follow-up care; and it is important that nurses are fully informed regarding the needs of cancer survivors. This paper aims to identify the needs of CRC survivors (via a survey-based quantitative assessment) and the relationship between need and QoL in order to inform practitioners and service providers about the issues faced by individuals living with and beyond CRC.

\section{Methods}

\section{Ethical considerations}

Ethical approval was given by the Office for Research Ethics Committees in Northern Ireland (ORECNI). Prior to data collection, steps were taken to ensure confidentiality and limit participant burden. Data were protected under the provisions of the UK Data Protection Act (1998).

\section{$\underline{\text { Study sample }}$}

A random sample of 600 CRC survivors, 2-15 years post-treatment, was generated from the Northern Ireland Cancer Registry (NICR) which is the most reliable source of cancer data in NI. The analysis adjusted for key variables including time of diagnosis. A questionnaire pack was mailed to the General Practitioner (GP) of each identified CRC survivor as stipulated by ORECNI in order safeguard patients and to eliminate inappropriate mailing to, for example, an individual who was in the end stages of life. This method provided a reasonably quick and inexpensive way 
of reaching a large and representative sample of CRC survivors. GPs screened patients to ensure that they had a diagnosis of CRC at 18+ years, were not receiving active treatment or end of life care for cancer and they had no cognitive impairment. Questionnaires were forwarded by GPs onto their CRC survivor patients who met the inclusion criteria. Survivors who agreed to participate were requested to return a consent form with their completed questionnaire. Reminder letters and a second copy of the research pack were sent to the GPs of non-respondents. It was not possible to send questionnaires directly to cancer survivors due to ethical concerns. Following data collection, the anonymous study numbers on questionnaires were used to match questionnaires with patient information from NICR in order to identify and compare respondents and non-respondents in terms of date of diagnosis, age, gender, level of deprivation, marital status, cancer site, urban/rural residence and Dukes Staging. In order to establish area level of deprivation, patient's postcodes were matched to the Northern Ireland Multiple Deprivation Measure (NIMDM, 2005).

\section{Outcome measures}

The Cancer Survivors Unmet Needs survey (CaSUN; Hodgkinson et al., 2007) and Quality of Life in Adult Cancer Survivors Scale (QLACS; Avis et al., 2006) were mailed to the sample of CRC survivors. The CaSUN consists of 35 needs measured over five domains: Existential Survivorship (14-items); Comprehensive Cancer Care (6-items); Information (3-items); QoL (2-items); and Relationships (3-items). Respondents indicated on a five-point Likert scale whether they had no need (scored 0 ) through to a strong unmet need (scored 4) within the last month. Items and domains were scored and categorised in terms of 'Met need', 'Unmet need', 'Total need', and 'Strength/severity of need'. All need items were summed to provide a total score with higher scores indicating greater needs (range 0-35). The CaSUN has good acceptability, internal consistency and validity (Hodgkinson et al., 2007). In addition and in order to ensure the applicability of the CaSUN in the NI context, feedback from key cancer HCPs on the CaSUN led to minor amendments such as changes to wording, the addition of 9 items and the removal of 1 item (fertility issues as survivors in this study were over 50 years old). The nine items added to the CaSUN included 'help with daily activities due to the changes in my body, access to GP, help to manage other illnesses, medication use, how to manage fatigue, coping with changes in appearance, followup review anxiety, worries and concerns following treatment and help to stay in contact after treatment'. The internal consistency of the modified version was 0.88 . 
The QLACS is a 47-item, self-administered multidimensional questionnaire which assesses QoL in the following domains: emotions, cognitive problems, pain, sexual functioning, social avoidance, fatigue, finance, recurrence concerns and family distress, benefits of cancer, positive feelings and appearance. Items were scored on a Likert scale ranging from 1 (never a problem) to 7 (always a problem). A review of QoL measures (Pearce et al., 2008) identified the QLACS as the best validated and most appropriate tool for the measurement of QoL of cancer survivors.

\section{$\underline{\text { Analysis }}$}

T-tests and chi-square analysis were used to compare survey respondents and non-respondents. Descriptive statistics were used to examine the prevalence of unmet need for individual items, needs domains and QoL. Linear regression was used to examine the relationship between total mean QoL and the reporting of unmet need. The model was adjusted for age, gender, marital status, locality, stage, site, time since diagnosis and level of deprivation. An identical approach was used to examine the relationship between unmet need and QOL in each CaSUN domain. Exploratory analysis showed that the data was appropriate for parametric testing. Data was analysed using SPSS version 19.

\section{Results}

Of the 600 CRC survivors sampled, 187 did not meet inclusion criteria (Fig 1) and 289 did not respond. The overall response rate was 30\% (124/413) (Fig 1). The mean age of respondents was 65 years old $(\mathrm{SD}=8)$ compared to 67 years old for non-respondents $(\mathrm{p}=0.01)$. There were no significant differences between respondents and non-respondents in terms of other demographic variables (see Table 1).

\section{$\underline{\text { Unmet needs }}$}

Sixty one percent of respondents reported having no unmet needs. Thirty-nine percent (48/124)

reported that they had unmet need (mean 3) (Table 2), with 10 of this 48 reporting more than 10 unmet needs. Over half (54\%) (21/39) of relatively younger survivors (aged 50-60) were 
significantly more likely to report unmet needs (Table 3). The ten most frequently cited unmet needs are summarised in Table 2, five of which were in the Information Domain of the CaSUN (Table 2). For example, the CRC survivors reported a need for information that was up-to-date (15\%) and understandable (14\%). Almost a quarter of respondents (23\%) reported information needs about life and travel insurance. In addition, 16\% of the CRC survivors reported that their families and partners had information needs.

Three of the ten most frequently reported unmet needs were care co-ordination (15\%), case managers (16\%) and availability of support services (16\%). Although hospital contact tended to be limited to (approx. twice yearly) follow-up review, 17\% of the CRC survivors reported a need for accessible hospital parking. Fear of recurrence was the only frequently cited psychological need (20\%). Twelve percent of respondents reported unmet fatigue needs and 6\% reported unmet needs in relation to subsidiary conditions. Eight percent of the CRC survivors reported body image needs and $12 \%$ highlighted a need for support to address problems regarding their sex life. Reviewrelated anxiety and worry was reported by only $6 \%$ of the CRC survivors.

\section{Quality of life}

Table 4 shows mean scores in each domain of the QLACS. Highest scores (poorer QoL) were reported for fatigue, benefits and distress recurrence issues. Lower mean QLACS scores were reported in the areas of social avoidance, finance and appearance. Survivors who stated that their needs were met had lower QoL scores (indicating better QoL) than CRC survivors who had unmet needs. The relationship between unmet and poorer QOL was consistent in all CaSUN domains (see Table 5) and remained after adjusting for other variables (gender, marital status, locality, and stage, site, time since diagnosis and level of deprivation). 


\section{Discussion}

The majority (61\%) of colorectal survivors reported no unmet needs. It is important to note that the sample of CRC survivors included patients who had colon and rectal tumours as well as patients for whom there was variation with respect to the variable, 'time since diagnosis'. UK studies of early stage cancer survivors, long-term survivors and myeloma cancer survivors have reported similarly low estimates of patient-reported unmet need (Armes et al., 2009, Molassiotis et al., 2010, Harrison et al., 2011). In contrast, non-UK studies of unmet need have estimated that 50$61 \%$ of cancer survivors report unmet needs (Thewes et al., 2004, Beesley et al., 2007, Barg et al., 2007, Hodgkinson et al., 2007, Zeebrack et al., 2007). These disparities may be attributed to various factors including variations in care provision levels, measurement tools and cancer sites under study. In particular, there is substantial variation internationally regarding cancer service financing, organisation, provision and delivery. Therefore, it is unsurprising that there is variation regarding the match between patient expectations, care needs and services across, for example, private insurance-based health care systems compared to public-funded care systems.

The findings of this study and other UK studies would appear to suggest that the majority of cancers survivors do not have additional service requirements and the need for specific follow-up support is required for only a minority of patients. However, it is important to bear in mind the possibility that pre-defined and professionally- or academically-generated measures of unmet need (Hodgkinson et al., 2007) may not afford survivors an opportunity to report their own specific CRC-related needs. Survivors of CRC may continue to experience difficulties with bowel movement, incontinence or stoma bag management after treatment has ended (Lai et al., 2013). Level of social connectedness or community participation may be reduced due to fears about not being able to manage their stoma bag in public places or being incontinent (McCaughan et al., 2011; Wilson et al., 2010). Also, CRC survivors may experience embarrassment and body image concerns related to their stoma (McCaughan et al., 2011), and they may have fears about food choices as well as specific dietary needs designed to alleviate symptoms (Anderson et al., 2013). It is possible that a qualitative assessment of CRC survivors' needs or a CaSUN-type cancer sitespecific questionnaire may have generated a different needs assessment profile. 
Travel insurance and accessible hospital car parking were among the most frequently cited unmet needs. Similar estimates of need for help to obtain insurance (19\%) and car parking (22\%) have been found in breast cancer survivors (Hodgkinson et al., 2007); such needs appear to be negligible among survivors of myeloma cancer (Molassiotis et al., 2010). Further research is required to investigate the degree to which the prevalence and nature of need varies across cancer sites (Lai et al., 2013). There may be merit in considering the extent to which there may be subgroups of survivors who may be at increased risk of experiencing need and, if so, planning and targeting services appropriately.

Fear of recurrence was reported by one fifth of survivors and one third of this proportion stated that this need was met. In contrast, health care professionals, particularly nurses, reported encountering high levels of fear of recurrence among their patients (Thewes et al., 2014). The strategies used by health professionals to help patients manage fear of recurrence appear to vary though data is lacking on this aspect of cancer care and the effectiveness of different support strategies. Indeed, there would appear to be a need to conduct further research and provide training in order to help nurses and other professionals address patients' concerns regarding anxietyrecurrence (Thewes et al., 2014). Survivors with a range of different cancers report fear of recurrence prevalence estimates ranging from 7\% to 32\% (Beesley et al., 2007, Hodgkinson et al., 2007, Molassiotis et al., 2010). Shun et al. (2014) found that CRC survivors with a Type D personality experienced greater needs; so, patients who tend to be anxious or experience events as stressful may be more likely to experience needs. There may be a need for multi-disciplinary teams to heighten their awareness of this tendency among some patients to become anxious and to make targeted efforts to assuage feelings of anxiety by, for example, asking patients about their worries and concerns, providing information to cancer survivors about the probability of cancer returning, prevention methods and what to do if they suspect recurrence (Mehta et al., 2003). Cancer survivors who have ongoing difficulties and worries regarding the fear that their cancer may return may benefit from anxiety management or counselling.

Similar to other studies (eg Shun et al., 2014), the small proportion of CRC survivors who experienced need appeared to have unmet information needs particularly in relation to finance information. A population-based survey of cancer survivors in Wales found that only around one 
half of patients received information about finance and benefits (Quality Health, 2014). The National Cancer Survivorship Initiative in England piloted interventions for cancer survivors such as an 'information prescription' that incorporated personalised information based on a patient's needs and preferences (Department of Health, 2010).

It would appear that the majority of cancer survivors within the UK do not report unmet needs. Only a small number of CRC survivors reported having psychological difficulties. Psychological needs have been identified as one of the priority needs in early survivorship (Armes et al., 2009). Survey participants may not have experienced significant psychological needs because they were two years post-diagnosis or, perhaps, through the passage of time the group of CRC survivors may have developed and refined their coping mechanisms. It may be the case also that psychological and sexual health needs are not as prevalent in CRC survivors compared to other cancer sites, or that CRC survivors (similar to prostate cancer survivors according to McCaughan et al., 2013) are reluctant to answer questions about sexuality. It is possible also that survey respondents compared to non-respondents comprise more survivors who have adjusted well to their cancer.

The CRC survivors who reported having one or more health and social care need had a reduced QoL, and this relationship was apparent in all CaSUN domains similar to other studies (Newell et al., 1999). The absence of reference values for the QLACS makes it difficult to interpret the generated scores. The scores in this study were comparable to QLACS scores among a sample of female cancer survivors (Kondapalli et al., 2013) and significantly lower than the scores reported by a group of healthy 'controls (Kondapalli et al., 2013). However, the scores of CRC survivors appeared to cluster around mid-scale indicating a relatively average to good QoL which is consistent with earlier studies (Ramsey et al., 2002, Rauch et al., 2004, Soerjomatarm et al., 2012, Farkkila et al., 2013). The generic nature of the QLACS did not facilitate the identification of site specific QoL and it is possible that CRC survivors may have reported poorer QoL had a CRCspecific measure been used that, for example, included questions about bowel health-related issues. A UK survey found that 19\% of CRC survivors have difficulty controlling their bowels and they are more likely to report poor QoL (DoH 2011). The relationship between needs and QoL is complex and there are a number of different needs-related variables which may impact on QoL but were not captured in this study such as needs at onset, patient satisfaction, psychosocial and 
treatment characteristics, co-morbidities, treatment type and levels of anxiety and depression (Mc Dowell et al, 2009, Hodgkinson et al, 2007, Beesley et al, 2009). Finally, this study provides a cross-sectional snapshot of the care needs of CRC survivors in one region of Europe and there is a need for further research using a longitudinal design, multi-factorial measures and comparator groups in order to answer key questions about the long-term service needs and QoL of the new, growing population of cancer survivors across Europe. 


\section{References}

Anderson, AS., Steele, R., Coyle, J., 2013. Lifestyle issues for colorectal cancer survivors perceived needs, beliefs and opportunities. Supportive Care in Cancer 21, 35-42.

Armes, J., Crowe, M., Richardson, A., 2009. Patients’ supportive care needs beyond the end of cancer treatment: a prospective, longitudinal survey. Journal of Clinical Oncology 27, 6172-6179. DOI:10.1200/jco.2009.22.5151

Avis, N., Ip, E., Long Foley, K., 2006. Evaluation of the Quality of Life in Adult Cancer Survivors (QLACS) Scale for long-term cancer survivors in a sample of breast cancer survivors. Health and Quality of Life Outcomes 4 DOI: 10.1186/1477-7525-4-92

Barg, F., Cronholm, P., Straton, J., Keddem, S., Knott, K., Grater, J., Houts, P., Palmer, S., 2007. Unmet Psychosocial Needs of Pennsylvanians with Cancer: 1986-2005. Cancer 11, 631639. DOI: 10.1002/cncr.22820.

Beaver, K., Latif, S., Williamson, S., Procter, D., Sheridan, J., Heath, J., Susnerwala, S., Luker, K., 2010. An exploratory study of the follow-up care needs of patients treated for colorectal cancer. Journal of Clinical Nursing 19, 3291-3300. DOI: 10.1111/j.1365-2702.2010.03407.x

Beesley, V., Eakin, E., Steginga, S., Aiken, J., Dunn, J., Battistutta, D., 2007. Unmet needs of gynaecological cancer survivors: implications for developing community support services. Psycho-oncology 17, 392-400. DOI: 10.1002/PON.1249

Bonevski, B., Sanson-Fisher, R., Girgis, A., Burton, L., Cook, P., Boyes, A., 2000. Evaluation of an instrument to assess the needs of patients with cancer. Cancer 88, $217-225$.

Bray, F., Ren, J., Masyer, E., Ferlay, J., 2013. Global estiamtes of cancer prevalence for 27 sites in the adult population in 2008. International Journal of Cancer 132, 1133-1145.

Cancer Research UK (2014) Bowel Cancer, Cancer Statistics Facts. http://publications.cancerresearchuk.org/downloads/Product/CS_KF_BOWEL.pdf

Deimling, G., Sterns, S., Bowman, K., Kahana, B., 2005. The Health of Older-Adult Long-term Cancer Survivors. Cancer Nursing 28, 415-424.

De Angelis, R., Sant, M., Coleman, M., Francisci, S., Baili, P., Pierannunzio, D. et al., 2013. Cancer survival in Europe 1999-2007 by country and age: results of EUROCARE-5-a population-based study. The Lancet Oncology 15, 23 - 34.

Department of Health., Macmillan Cancer Support., National Health Service Improvement., 2010. National cancer survivorship vision. 
Department of Health., 2011 Quality of Life of Cancer Survivors in England Report on a pilot survey using Patient Reported Outcome Measures. Department of Health.

Eakin, E., Yourdon, D., Baade, P., Lawler, S., Reeves, M., Heyworth, J., Fritschi, L., 2007. Health behaviours of Cancer Survivors: data from a population based Australian Survey. Cancer Causes Control 18, 881-894. DOI: 10. 1007/s 1007/s10552-0079033-5

Elliott, J., Fallows, A., Staetsky, L., Smith,P., Foster, C., Maher, J. Corner, J., 2011 The health and well-being of cancer survivors in the United Kingdom: findings from a population-based survey. British Journal of Cancer 105, S11-S20

Färkkilä, N., Sintonen, H., Saarto, T., Järvinen, H., Hänninen , J., Taari, K., Roine, R., 2013 Health-related quality of life in colorectal cancer, 15, 5, e215-e222

Gotay, C., Pagano, I., 2007. Assessment of survivors concerns (ASC): a newly proposed brief questionnaire. Quality of Life Outcomes 5, 15-26. DOI: 10.1186/1477-7525-5

Harrison, S., Watson, E., Ward, A., Khan, N., Turner, D., Adams, E., Forman, D., Roche, M., Rose, P., 2011. Primary health and supportive care needs of long-term cancer survivors: a questionnaire survey. Journal of Clinical Oncology 29, 2091 - 2098.

Hewitt, M., Rowland, J., Yancik, R., 2003. Cancer survivors in the United States: Age Health and Disability. The Journals of Gerontology Series A: Biological Sciences and Medical Sciences 58, 82-91. Doi: 10.1093/Gerona/58.1

Hodgkinson, K., Butow, P., Hunt, G., 2007. The development and Evaluation of a measure to assess cancer survivors unmet supportive care needs: The Cancer Survivors Unmet Needs Measure. Psycho-Oncology 16, 796-804, DOI:10.1002/pon.1137

Hodgkinson, K. Butow, P. Hunt, G. Pendlebury, S. Hobbs, K. Wain, G., 2007. Breast cancer survivors' supportive care needs 2-10 years after diagnosis. Supportive Care Cancer 15 (5), 515523. DOI: $10.1007 / \mathrm{s} 00520-006-0170-2$

Horner, M., Ries, L., Krapcho M., 2008. SEER Cancer Statistics Review 1975-2006. National Cancer Institute. Bethesda, MD.

Keating, N., Norredam, M., Landrum, M., Huskamp, H., Meara, E., 2005. Physical and Mental Health Status of Older Long-Term Cancer Survivors. Journal of the American Geriatrics Society 53, 2145-2152. DOI:10.1111/j.1532-5415.2005.00507.x

Kondapalli, L., Dillon, K., Sammel, M., Ray, A., Prewitt., M. Ginsberg, J. Gracia., C., 2013 Quality of life in female cancer survivors: is it related to ovarian reserve. Quality of Life Research, 1-8. 
Lai, X., Wong, F., Ching, S., 2013. Review of bowel dysfunction of rectal cancer patients during the first five years after sphincter-preserving surgery: A population in need of nursing attention. European Journal of Oncology Nursing 17, 681- 692.

Maddams, J., Moller, H., Brewster, D., Gavin, A., Steward, J., Elliot, J., Utley, M., 2009. Cancer prevalence in the United Kingdom: estimates for 2008. British Journal Cancer 101, 541-547. DOI: 10.1038/sj.bjc.6605148

Mehta, S., Lubeck, D., Pasta, D., Litwin, M., 2003. Fear of cancer recurrence in patients undergoing definitive treatment for prostate cancer: Results from CaPSure. The Journal of Urology 170, 1931-1933.DOI: 10.1097/01.JU.0000091993.73842.9b

Miles, M., Hurberman, M., 1994. Qualitative Data Analysis: an expanded sourcebook. Second edition. London, Beverley Hills. Sage Publication.

Molassiotis, A., Blair, S., Wilson, B., 2010. Unmet supportive care needs, psychological wellbeing and quality of life in patients living with multiple myeloma and their partners. PsychoOncology 20, 88-97. DOI:10.1002/PON.2710.

Mc Caughan, E., Mc Sorley, O., Prue, G., Parahoo, K., Bunting, B., O Sullivan, J., McKenna,H. 2013 Quality of life in men receiving radiotherapy and neo-adjuvant androgen deprivation for prostate cancer: results from a prospective longitudinal study. Journal of Advanced Nursing. 69.53-65.

McCaughan, E., Prue, G., Parahoo, K., Mcllfatrick, S., McKenna, H., 2011. Exploring and comparing the experience and coping behaviour of men and women with colorectal cancer at diagnosis and during surgery. Journal of Advanced Nursing 67, 1591-1600.

McDowell, M., Occhipinti., Ferguson., M. Dunn, J., Chambers S. 2010 Predictors of change in unmet supportive care needs in cancer. Psychoonclogy. 5. 508-16. DOI: 1002/PON.1604.

Newell, S., Sanson-Fisher, R., Girgis, A., Ackland, S., 1999. The physical and psycho-social experiences of patients attending an outpatient medical oncology department: a cross sectional study. European Journal of Cancer 8, 73-82. DOI: 10.1046/J.1365-2354.1999.00125.X

Nord, C., Mykletun, A., Thorsen, L., Bjoro, T., Fossa, S., 2005. Self-reported health and use of health services in long term survivors. International Journal of Cancer 114, 307-316. DOI: 10.1002/ijc. 20713

Northern Ireland Statistics and Research Agency., 2005. Northern Ireland Multiple Deprivation Measure. May 2005

Quality Health. 2014. Wales Cancer Patient Experience Survey, National Report 
Pearce, N., Sanson-Fisher, R., Campbell, H., 2008. Measuring quality of life in cancer survivors: a methodological review of existing scales. Psycho-Oncology 17, 629-640. DOI: 10.1002/PON.1281

Portenoy, R., Loretta, M., 1999. Cancer Related Fatigue: Guidelines for Evaluation and Management. The Oncologist 4, 1-10

Rauch, P., Miny,J., Conroy, T., Neyton, L., Guillemin, F., 2004. Quality of Life Among DiseaseFree Survivors of Rectal Cancer. Journal of Clinical Oncology 22, 354-360.

Reeve, B., Potosky, A., Wilder Smith, A., et al., 2009. Impact of cancer on health-related quality of life of older Americans. Journal of the National Cancer Institute 101, 860-868. DOI: 10.1093/jnci/djp

Richards, M., Corner, J., Maher, J. 2011 The National Cancer Survivorship Initiative: new and emerging evidence on the ongoing needs of cancer survivors. British Journal of Cancer 105, S1S4. doi:10.1038/bjc.2011.416

Rowland, J., Kent, E., Forsythe, L., Harvard Loge, J., Hjorth, L., Glaser, A., Mattioli, V., Fossa, S., 2013. Cancer Survivorship Research in Europe and the United States: Where Have We Been, Where Are We Going, and What Can We Learn From Each Other? Cancer 119, 2094-108.

Santin, O., Mills, M., Treanor, C., Donnelly, M., 2012. A comparative analysis of the health and well-being of cancer survivors to the general population. Supportive Care in Cancer 20, 25452552.

Santin, O., Mills, M., Treanor, C., Donnelly, M., 2013. The health status and health service needs of primary caregivers of cancer survivors: a mixed methods approach. European Journal of Cancer Care Article first published online: 9 DEC 2013. DOI: 10.1111/ecc.12157.

Schultz, P.N., Beck, M.L., Stava, C., Vassilopoulou-Sellin, R., 2003. Health profiles in 5386 longterm cancer survivors. International Journal of Cancer 104, 488-95. DOI:10.1002/IJC.10981

Soerjomataram, I., Thong, M., Ezzati, M., Lamont, E., Nusselder, W., van de Poll-Franse. L., 2012. Most colorectal cancer survivors live a large proportion of their remaining life in good health. Cancer Causes \& Control 23, 1421-1428.

Shun, S-C., Yeh, K-H., Liang, J-T., Huang, J., Chen, S-C., Lin, B-R., Lee, P-H., Lai. Y-H., 2014. Unmet Supportive Care Needs of Patients With Colorectal Cancer: Significant Differences by Type D Personality. Oncology Nursing Forum, 41

Thewes, B., Butow, P., Girgis, A., Pendlebury, S., 2004. Assessment of unmet needs among survivors of breast cancer. Journal of Psychosocial Oncology 22, 51-73. 
Thewes, B., Brebach, R., Dzidowska, M., Rhodes, P., Sharpe, L., Butow, P., 2014. Current approaches to managing fear of cancer recurrence; a descriptive survey of psychosocial and clinical health professionals. Psycho-Oncology 23, 390-396.

Rowland, J., Kent, E., Forsythe, L., Harvard Loge, J., Hjorth, L., Glaser, A., Mattioli, V., Fossa, S., 2013. Cancer Survivorship Research in Europe and the United States: Where Have We Been, Where Are We Going, and What Can We Learn From Each Other? 119, 2094-108.

Yabroff, R., Lawrence, W., Clauser S., et al., 2004. Burden of illness in cancer survivors: findings from a population-based national sample. Journal of the National Cancer Institute 96, 1322-30. DOI: 10.1093/JNCI/djh255.

Wilson, T.R., Birks, Y.F., Alexander, D.J., 2010.A qualitative study of patient perspectives of health related quality of life in colorectal cancer: comparison with disease specific evaluation tools. Colorectal Disease 12, 762-769.

Zebrack, B., Mills, J., Weitzman, T., 2007. Health and supportive care needs of young adult cancer survivors. Journal of Cancer Survivorship 1, 137-145. DOI: 10. 1007/s11764-007-0015-0 
Table 1: Characteristics of respondents compared to non-respondents

\begin{tabular}{|c|c|c|c|c|}
\hline & $\begin{array}{c}\text { Respondents } \\
\mathrm{n}=124\end{array}$ & $\begin{array}{l}\text { Non-respondents } \\
\qquad \mathrm{n}=289\end{array}$ & $\mathrm{df}$ & $\mathrm{p}$ \\
\hline Female & 52 & 150 & 1 & 0.07 \\
\hline Male & 72 & 139 & & \\
\hline Mean average age & 65 & 67 & & 0.01 \\
\hline Married & 91 & 194 & 1 & 0.2 \\
\hline Not Married & 33 & 95 & & \\
\hline Dukes Staging & & & 3 & 0.23 \\
\hline A (least advanced) & 15 & 40 & & \\
\hline B & 51 & 100 & & \\
\hline $\mathrm{C}$ & 25 & 58 & & \\
\hline D (most advanced) & 3 & 1 & & \\
\hline Unknown & 30 & 30 & & \\
\hline Urban & 80 & 176 & 1 & 0.51 \\
\hline Rural & 44 & 113 & & \\
\hline Time since diagnosis & & & 3 & 0.98 \\
\hline $2-5$ years & 64 & 190 & & \\
\hline 6-10 years & 39 & 66 & & \\
\hline $11+$ & 21 & 28 & & \\
\hline Social deprivation score & & & 2 & 0.51 \\
\hline Most deprived & 43 & 100 & & \\
\hline Moderate & 54 & 112 & & \\
\hline Least & 27 & 77 & & \\
\hline
\end{tabular}


Table 2: Self-reported colorectal cancer survivor unmet and met needs

\begin{tabular}{|c|c|c|c|c|c|c|c|c|c|}
\hline Type of unmet need & No. & $\begin{array}{l}\text { \% unmet } \\
\text { need }\end{array}$ & $\begin{array}{l}\text { \% need } \\
\text { met }\end{array}$ & $\begin{array}{l}\text { \% no } \\
\text { need }\end{array}$ & Type of met need & No. & $\begin{array}{l}\text { \% need } \\
\text { met }\end{array}$ & $\begin{array}{l}\text { \% no } \\
\text { need }\end{array}$ & $\begin{array}{l}\text { \% unmet } \\
\text { need }\end{array}$ \\
\hline I need help getting life/travel Insurance & 1 & 22.5 & 10.8 & 66.7 & I need access to my GP & 1 & 62.2 & 26.1 & 11.7 \\
\hline $\begin{array}{l}\text { I need help to manage my recurrence } \\
\text { concerns }\end{array}$ & 2 & 20.3 & 48.7 & 31.0 & $\begin{array}{l}\text { I need to feel that I am managing my } \\
\text { health with the medical team }\end{array}$ & 2 & 45.2 & 43.5 & 11.2 \\
\hline I need more accessible hospital parking & 3 & 16.8 & 70.8 & 12.4 & I need the very best medical care & 3 & 44.0 & 44.0 & 12 \\
\hline $\begin{array}{l}\text { I need a case manager to find out about } \\
\text { services when I need them. }\end{array}$ & 4 & 15.9 & 6.2 & 77.9 & $\begin{array}{l}\text { I need local health services that are } \\
\text { available when I require them }\end{array}$ & 4 & 39.7 & 44.8 & 15.6 \\
\hline $\begin{array}{l}\text { My family/partner needs information that is } \\
\text { relevant to them. }\end{array}$ & 5 & 15.6 & 13.7 & 70.9 & I need help to manage other illnesses & 5 & 39.0 & 51.7 & 9.3 \\
\hline $\begin{array}{l}\text { I need local health services that are available } \\
\text { when I need them }\end{array}$ & 6 & 15.6 & 39.7 & 44.8 & $\begin{array}{l}\text { I need help to stay in contact after } \\
\text { treatment }\end{array}$ & 6 & 35.1 & 56.1 & 8.8 \\
\hline $\begin{array}{l}\text { I need information on financial support or } \\
\text { government benefits }\end{array}$ & 7 & 15.3 & 10.7 & 74.1 & $\begin{array}{l}\text { I need help to manage my recurrence } \\
\text { concerns }\end{array}$ & 7 & 31 & 48.7 & 20.3 \\
\hline $\begin{array}{l}\text { I need to know that all my doctors talk to each } \\
\text { other to co-ordinate my care }\end{array}$ & 8 & 14.8 & 45.2 & 40 & $\begin{array}{l}\text { I need complaints regarding my care to } \\
\text { be properly addressed }\end{array}$ & 8 & 28.7 & 60 & 11.3 \\
\hline I need up to date information & 9 & 14.5 & 21.4 & 64.1 & $\begin{array}{l}\text { I need help with my worries and } \\
\text { concerns following treatment }\end{array}$ & 9 & 28.1 & 63.2 & 8.8 \\
\hline I need understandable information & 10 & 13.7 & 21 & 59.7 & $\begin{array}{l}\text { I need help in relation to follow up } \\
\text { anxiety }\end{array}$ & 10 & 24.6 & 66.7 & 8.7 \\
\hline
\end{tabular}


Table 3: Profile of survivors with unmet needs compared to no needs/needs met

\begin{tabular}{|c|c|c|c|c|}
\hline Variable & & Unmet need (\%) & No Need/Need Met & $\mathbf{P}$ \\
\hline Sex & $\begin{array}{l}\text { Male } \\
\text { Female }\end{array}$ & $\begin{array}{l}31(43 \%) \\
17(32 \%)\end{array}$ & $\begin{array}{l}41(57.3 \%) \\
35(68 \%)\end{array}$ & 0.24 \\
\hline Age & $\begin{array}{l}50-59 \\
60-69 \\
70+\end{array}$ & $\begin{array}{l}21(53.8 \%) \\
14(29.2 \%) \\
13(35.1 \%)\end{array}$ & $\begin{array}{l}18(46.2 \%) \\
34(70.8 \%) \\
24(64.9 \%)\end{array}$ & 0.05 \\
\hline Marital Status & $\begin{array}{l}\text { Married } \\
\text { Not Married }\end{array}$ & $\begin{array}{l}6 \text { (39.6\%) } \\
12(36.4 \%)\end{array}$ & $\begin{array}{l}55(60.4 \%) \\
21(63.6 \%)\end{array}$ & 0.75 \\
\hline Locality & $\begin{array}{l}\text { Urban } \\
\text { Rural }\end{array}$ & $\begin{array}{l}30 \text { (37.5\%) } \\
18(40.9 \%)\end{array}$ & $\begin{array}{l}50(62.5 \%) \\
26(59.1 \%)\end{array}$ & 0.70 \\
\hline $\begin{array}{l}\text { Level of } \\
\text { deprivation }\end{array}$ & $\begin{array}{l}\text { Most Deprived } \\
\text { Moderately } \\
\text { Least Deprived }\end{array}$ & $\begin{array}{l}15(34.9 \%) \\
20(37.0 \%) \\
13(48.1 \%)\end{array}$ & $\begin{array}{l}28(65.1 \%) \\
34(63 \%) \\
14(51.9 \%)\end{array}$ & 0.51 \\
\hline Cancer Site & $\begin{array}{l}\text { Colon } \\
\text { Rectum }\end{array}$ & $\begin{array}{l}29(37.7 \%) \\
19(40.4 \%\end{array}$ & $\begin{array}{l}48(62.3 \%) \\
28(59.6 \%)\end{array}$ & 0.76 \\
\hline $\begin{array}{l}\text { Time Since } \\
\text { Diagnosis }\end{array}$ & $\begin{array}{l}2-5 \text { years } \\
6-10 \text { years } \\
11+\end{array}$ & $\begin{array}{l}25(39 \%) \\
13(21.3 \%) \\
10(47.6 \%)\end{array}$ & $\begin{array}{l}39(60.9 \%) \\
26(66.7 \%) \\
11(52.4 \%)\end{array}$ & 0.55 \\
\hline Dukes Staging & $\begin{array}{l}\mathrm{A} \\
\mathrm{BC} \\
\mathrm{D}\end{array}$ & $\begin{array}{l}8(53.3 \%) \\
34(66.7 \%) \\
15(53.6 \%)\end{array}$ & $\begin{array}{l}7(46.7 \%) \\
17(33.3 \%) \\
13(46.4 \%)\end{array}$ & 0.42 \\
\hline
\end{tabular}


Table 4: Summary of Mean Quality of Life Domain Scores (QLACS)

\begin{tabular}{|c|c|c|c|}
\hline Domain & Mean Total Score & Sd & Range (Min/Max) \\
\hline Fatigue & 19.1 & 5.5 & $5-28$ \\
\hline Benefits of cancer & 13.6 & 3.9 & $4-23$ \\
\hline Distress Recurrence & 11.29 & 5.8 & $4-28$ \\
\hline Sexual problem & 10.9 & 6.5 & $4-28$ \\
\hline Positive Feelings & 10.8 & 5.7 & $4-28$ \\
\hline Pain & 10.5 & 5.7 & $4-26$ \\
\hline Negative Feelings & 10.6 & 4.4 & $4-25$ \\
\hline Cognitive Problems & 10.4 & 4.6 & $4-26$ \\
\hline Family Distress & 10.3 & 5.9 & $3-23$ \\
\hline Social Avoidance & 8.8 & 4.7 & $4-23$ \\
\hline Finance & 6.5 & 6.5 & $4-27$ \\
\hline Appearance & 1.3 & 2.9 & $0-16$ \\
\hline Generic QoL & 91 & 15 & $0-42$ \\
\hline Cancer Specific QoL & 29 & 13 & $0-35$ \\
\hline Total QLACS Score & 125.1 & 30.4 & $0-343$ \\
\hline
\end{tabular}


Table 5: Linear Regression between Total QoL score and unmet need

\begin{tabular}{|c|c|c|c|c|c|}
\hline $\begin{array}{l}\text { *Need measured } \\
\text { by CaSUN }\end{array}$ & $\begin{array}{l}* * \text { Mean } \\
\text { difference }\end{array}$ & $\mathbf{P}$ & $\begin{array}{l}95 \% \\
\text { CI }\end{array}$ & $\begin{array}{l}* * * \text { Difference in } \\
\text { mean adjusted for } \\
\text { age and sex }\end{array}$ & $\begin{array}{l}* * * * \text { Difference in } \\
\text { mean*adjusted for } \\
\text { all variables }\end{array}$ \\
\hline $\begin{array}{l}\text { General } \\
\text { No Need }\end{array}$ & -16 & 0.00 & $\begin{array}{l}-26.2 \\
-5.62\end{array}$ & $-18(-29,-7)$ & $-18(-30,-7)$ \\
\hline $\begin{array}{l}\text { Existential } \\
\text { No need }\end{array}$ & -38 & 0.0 & $-50,25$ & $(-48,-22)$ & $(-50,-23)$ \\
\hline $\begin{array}{l}\text { Comprehensive } \\
\text { Cancer Care } \\
\text { No Need }\end{array}$ & -20 & 0.0 & $-34,-7$ & $(-32,-5)$ & $(-35,-6)$ \\
\hline $\begin{array}{l}\text { Information } \\
\text { Domain } \\
\text { No need }\end{array}$ & -18 & 0.0 & $-32,-4$ & $(-35,-8)$ & $(-39,-10)$ \\
\hline $\begin{array}{l}\text { Quality of Life } \\
\text { No Need }\end{array}$ & -30 & 0.0 & $-51,-8$ & $(-52,-11)$ & $(-56,-13)$ \\
\hline $\begin{array}{l}\text { Relationship } \\
\text { No Need }\end{array}$ & -27 & 0.0 & $\begin{array}{l}-44,- \\
10\end{array}$ & $(-42,-8)$ & $(-44,-9)$ \\
\hline
\end{tabular}

*Domain of need as measured on the CaSUN, ** Mean difference in QLACS between those reporting no needs and those reporting need, *** mean difference in QLACS between those reporting no needs and unmet needs when adjusted for age and sex, ${ }^{* * *}$ main difference in QLACS score between those reporting no needs and unmet needs when adjusted for all other variables. 
Fig 1: Flowchart showing sampling and recruitment process

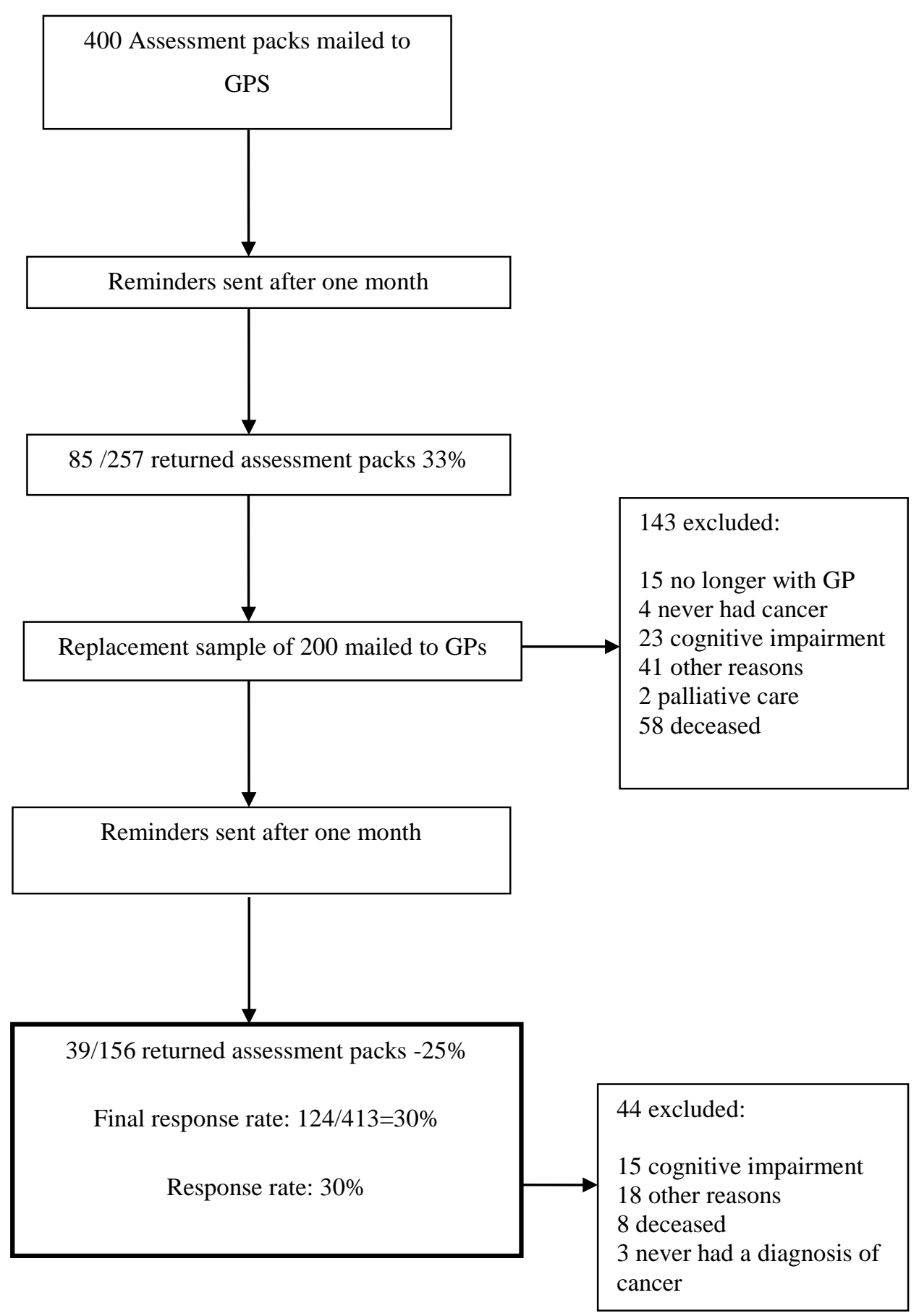

